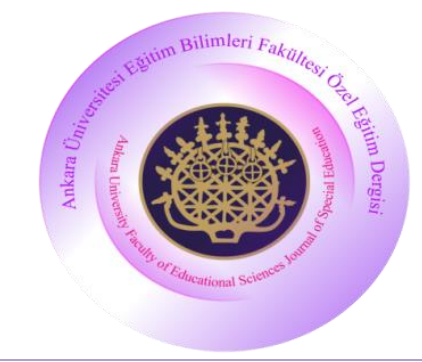

\section{Ankara Üniversitesi Eğitim Bilimleri Fakültesi Özel Eğitim Dergisi}

Yıl: 2018, Cilt: 19, Sayı: 3, Sayfa No: 531-551

DOI: 10.21565/ozelegitimdergisi.348310

\title{
İşiten ve İșitme Yetersizliği Olan Öğrencilerin Özetleme Becerilerinin Karşılaştırmalı Olarak İncelenmesi
}

\author{
Halime Miray Sümer \\ Niğde Ömer Halisdemir Üniversitesi
}

\author{
Cebrail Turna ${ }^{(D * *}$ \\ Ankara Üniversitesi
}

\begin{abstract}
Öz
Bu çalışmada sekizinci sınıfta öğrenim gören işiten ve işitme yetersizliği olan öğrencilerin öyküleyici metinleri özetleme becerileri ve oluşturulan metinlerin bağdaşıklık düzeyleri açısından değerlendirilmesi amaçlanmıştır. Araştırmanın çalışma grubunu Ankara'da sekizinci sınıfta öğrenim gören 15 işitme yetersizliği olan öğrenci ile 15 işiten öğrenci oluşturmaktadır. Yapılan analiz sonucunda özetlemenin içerik, biçim, dil ve anlatım, metin yapısı alt boyutlarında ve özetleme toplam puanında işitme yetersizliği olan öğrenciler ve işiten öğrenciler arasında anlamlı bir fark bulunmuştur. İșiten öğrencilerin özetleme becerisinin alt boyutlarına ilişkin puanları ve özetleme becerisi toplam puanlarının işitme yetersizliği olan öğrencilere göre daha yüksek olduğu görülmüştür. Bağdaşıklık düzeyinde ise gönderim, eksiltili anlatım, bağlama ögeleri alt boyutlarında ve bağdaşıklık araçlarını toplam kullanım sıklıklarında işitme yetersizliği olan öğrenciler ve işiten öğrenciler arasında anlamlı bir fark bulunmuştur. Bağdaşıklık düzeyinin değiştirim alt boyutunda işiten ve işitme yetersizliği olan öğrenciler arasında anlamlı bir fark bulunmamıştır.
\end{abstract}

Anahtar sözcükler: İşitme yetersizliği olan öğrenciler, özetleme stratejisi, bağdaşıklık.

\section{$\underline{\text { Önerilen Atı Sekli }}$}

Sümer, H. M., \& Turna, C. (2018) İşiten ve işitme yetersizliği olan öğrencilerin özetleme becerileri açısından incelenmesi. Ankara Üniversitesi Eğitim Bilimleri Fakültesi Özel Eğitim Dergisi, 19(3), 531-551. doi: 10.21565/ozelegitimdergisi.348310

*Sorumlu Yazar: Arş. Gör., E-posta: miraysumer@ gmail.com, http://orcid.org/0000-0002-1470-8195

${ }^{* *}$ Arş. Gör., E-posta: cebrailturna@ @mail.com, https://orcid.org/0000-0002-3817-1951 
Okuma, bireyin tüm hayatını özellikle de akademik yaşamını etkileyen önemli bir beceridir. Okuma becerisindeki yetkinlik başarılı bir akademik performansın göstergesi iken bu beceride yaşananan sınırlılıklar da akademik başarısızlığın önemli etkenlerinden biridir (Justice, Invernizzi, Geller, Sullivan ve Welsch, 2005). En genel tanımıyla yazılı sembollerden anlam çıkarma süreci olan okuma tüm alt boyutlarını kapsayacak şekilde ;

“okuyucuların yazılı metinlerde yer alan sözcükleri uygun ortografik, sesbilgisel, morfolojik bilgi ve becerilerini kullanarak çözümledikleri, ardından çözümlenen sözcükleri varolan sözcük dağarcıkları, önceki bilgi ve deneyimleri ile bağdaştırarak anlamlandırdıkları, sonrasında ise anlamlandırdıkları sözcüklerden oluşan cümleleri sözdizimsel özellikleri bağlamında analiz edip verilmek istenen mesaja ulaşabildikleri bir süreç" olarak tanımlanmıştır (Güldenoğlu, Kargın ve Miller, 2014).

Alanyazındaki okuma tanımları incelendiğinde okumanın, çözümleme ve anlama olmak üzere iki basamaktan oluştuğu ve asıl amacının ise okuduğunu anlama olduğu görülmektedir. Anlamanın gerçekleşmediği bir okuma eylemi ancak sesletim olarak isimlendirilebilir. Formal ve informal olarak değerlendirilen (Tarchi, 2015) okuduğunu anlama becerisini değerlendirme yöntemlerinden biri de öğrencilerin okudukları metinleri özetlemeleridir (Braxton, 2009; Cavkaytar, 2010; Jitendra ve Gajria, 2011; Solomon, 2012). Özetleme, okunan metnin akışını bozmadan önemli bilgileri içerecek şekilde okuyucunun metni kendi cümleleri ile kısaltmasıdır (Aktaş ve Bayram, 2017; Braxton, 2009; Çıkrıkçı, 2008; Deneme, 2009; Görgen, 1997). Tanımdan da anlaşıldığı gibi özetleme metindeki cümlelerin ezbere yazılması değil, metin içindeki önemli noktaları daha önemsiz olanlardan ayırıp ana düşünceyi ifade etme biçimidir. Özetleme yaparken birey, analiz yapma, sınıflandırma, sonuç çıkarma, çıkarımda bulunma gibi birtakım bilişsel görevleri de yerine getirmektedir (Erdem, 2012). Alanyazın incelendiğinde özetlemenin okunan metne ilişkin bilgilerin hatırlanmasını kolaylaştırdığı ve okuduğunu anlama performansını artırdığı görülmektedir (Calp, 2010; Calhoon, 2005; Graham ve Harris, 2012; Kim, Linan-Thompon ve Misquitta, 2012; Westby, Culatta, Lawrence ve Hall-Kenyon, 2010).

Hem okuma hem de yazma becerileriyle ilişkili olan özetmeleme becerisi (Belet ve Yaşar, 2007; Senemoğlu, 2005; Tok ve Beyazıt, 2007), kendiliğinden gelişen bir beceri olmayıp öğretim yoluyla kazandırılan bir beceridir (Akyol, 2008; Anderson, Hidi ve Babadoğan, 1991). Başarılı ve etkili bir özetleme yapabilmek için öğrencilerin okudukları metni iyi bir şekilde anlamaları, önemli olan yerleri önemsizlerden ayırmaları, olay akışını bozmamaları, fazla kelime kullanımından kaçınmaları ve noktalama işaretleri ile yazım kurallarına dikkat etmeleri gerekmektedir (Beyreli, Çetindağ ve Celepoğlu, 2005; Güneş, 2007). Ayrıca, metnin yapısı (bilgilendirici, hikaye edici vs), okuyucunun yaşı ve okuma deneyimleri gibi faktörler de özetlemeyi etkilemektedir (Akyol, 2008; Tompkins, 2006).

Akyol'a (2008) göre hikaye edici metinler diğer metin türlerine göre ve kısa olan metinler uzun olanlara göre daha kolay özetlenmektedir. Açıklayıcı ve bilgilendirici metinler, karmaşık ve okuyucuların tanıdık olmadıkları sözcüklerin sayısının daha fazla olması nedeniyle daha zor özetlenmektedir (Anderson ve di ̌̆., 1991). Bulut (2013), 5. sınıfa devam etmekte olan 561 öğrenci ile yapmış olduğu çalışmada öğrencilerin özetleme performanslarını incelemiş ve öğrencilerin hikaye edici metin türünde bilgi verici metinlere göre daha başarılı olduğu sonucuna ulaşmıştır. Metin türünden başka özetlemeyi etkileyen kriterlerden biri de okuyucuların yaşıdır (Bulut, 2013). Okuyucuların yaşlarının artmasıyla daha fazla okuma deneyimine sahip olmalarından dolayı özetleme performansları da daha yüksek olmaktadır.

Okunulan metne dair cümleler üstü ilişkileri inceleyen metindilbilimine göre metinler bir bütün olarak cümlelerin birbirleri arasındaki ilişkisine ve etkileşimine bağlı olarak anlam kazanmaktadır (Özkan, 2004). De Beaugrande ve Dressler (1981) tarafindan ürünün oluşturabilmesi için yedi öge önemli görülmektedir. Bunlar; bağdaşıklık, tutarlılık, amaçlılık, metin içi ilişki, kabul edilebilirlik, bilgi vericilik ve duruma uygun olmadır (Akt., Coşkun, 2005).

Metni oluşturan cümleler birbirileriyle bir ilişki içinde olmak zorundadır. Bu nedenle cümleler birbirlerinden bağımsız değil, aksine birbirlerini tamamlayan yapılardır. Böylece cümleler, gerçek yani vermek 
istediği mesajı açık ve net bir şekilde ifade edebilen yapılara dönüşmektedir. Halliday ve Hasan (1976) tarafindan metni bir arada tutan, anlam yükleyen ve metni metin olmayan söylemlerden ayıran şeyin bağdaşıklık olduğu açıklanmaktadır (Akt., Coşkun, 2005). Bağdaşıklık genel itibariyle yazılan bir şeyin metin olarak tanımlanmasını sağlayan ve metnin sürekliliğini sağlayan dile ilişkin özellikler bütünüdür (Yılmaz, 2012; Yue, 1993; Akt., Coşkun, 2005).

Bu çalışmada Coşkun (2005) tarafından Türkçe'ye uyarlanan Halliday ve Hasan'ın (1976) “Cohension in English" isimli çalışması çerçevesinde bağdaşıklık gönderim, eksiltili anlatım, değiştirim ve bağlama ögeleri olmak üzere dört temel başlıkta değerlendirilmiştir.

Gönderim, metin içerisinde ifade edilen bir kavramın ya da varlığın, aynı cümle içinde ya da yakın cümlelerde tekrar edilmeyip başka bir sözcük ya da ek ile ifade edilmesidir. Örneğin, "Berat kitaplarına çok değer verirdi. Küçük kardeşim onları yırtınca çok üzülmesine rağmen yine de ona kızamadı." cümlelerinde ikinci cümlede yer alan onları zamiri ilk cümlede geçen kitaplara gönderim yaparken $o$ zamiri de Berat'ın küçük kardeşine gönderim yapmaktadır. Böylelikle iki cümle arasında anlam ilişkisi oluşturan bir gönderim oluşmuştur.

Türkçe'de gönderim ögeleri şahıs zamirleri, dönüşlülük zamiri, işaret zamiri, ilgi zamiri, işaret sıfatları ve karşılaştırma yoluyla yapılmaktadır (Coşkun, 2005). Şahıs zamirleri (ben, sen, o, biz, siz, onlar) metin içerisinde bir kişiye ilişkin gönderimde bulunmak amacıyla kullanılır. Örnek olarak, "Mert ve Burak toplantıya geç kalmışlard1. İçeri girdiklerinde onlardan başka herkesin geldiğini gördüler.” cümlesinde “onlar” zamiri ile Mert ve Burak'a gönderimde bulunulmuştur. Ayrıca Türkçe'nin sondan eklemeli bir dil olmasından dolayı eyleme gelen ekler özneyi işaret edebilir. Örnek olarak, "Hızlı bir şekilde yolda ilerlerken aniden köşedeki dükkana bir sahaf açıldığını gördüm. Bir anda her şeyi unuttum ve telaşlı bir şekilde içeri girdim.” cümlesinde eylemlerin sonuna gelen ek cümlenin ögesinin 1. tekil kişi olan "ben” olduğunu göstermekte ve bir gönderim yapmaktadır. "Kendi" kelimesi ve bu kelimenin iyelik ekleri ile dönüşlülük zamiri olarak adlandırılmaktadır. Dönüşlülük zamiri özneyi pekiştirmekle (Korkmaz, 2003) birlikte eylemin gerçekleştirene dönüşünü göstermektedir (Arslan-Erol, 2010). "Bu noktalara kendim geldim, kimseden yardım görmedim.” cümlesinde kendim dönüşlülük zamiri bizzat ben anlamı katmakla birlikte özneye gönderimde bulunmuştur. İşaret zamirleri ise nesne ve kavramların yerini belirten zamirlerdir. Genel olarak işaret zamirleri ise "bu, şu, o, bunlar, şunlar, öteki, beriki, orada, burada..." şeklindedir. Örneğin, "Cüzdanını kaybetmişti. Onu getirene ufak bir hediye verecekti." cümlesinde "o" zamiri cüzdanı işaret etmektedir ve iki cümle arasında bir gönderim ortaya çıkarmaktadır. Bir diğer gönderim yapan zamir türü ise ilgi zamiridir. Türkçe'de ilgi zamiri ise "ki”" zamiridir. "Mehmet' in telefonu Orhan'ınkinden daha eski." cümlesinde ilgi zamiri olan “ki” Orhan'ın telefonu anlamı taşımakta ve bir gönderim yapmaktadır.

Gönderim yapan ögelerden bir diğeri de işaret sıfatlarıdır. Genel olarak işaret sıfatları “o, bu, şu, diğer, öteki, beriki...” şeklindedir. Örnek olarak "Koşarak kitabevine girdi. Kitabın adının olduğu kağıdı görevliye uzattı. Fakat o kitabı biraz önce satmışlardı.” cümlesindeki “o kitabı” öznenin aradığı kitabı işaret etmekte ve ayrıca gönderim yapmaktadır.

Gönderim türlerinden biri de karşılaştırma yoluyla yapılan gönderimdir. Türkçe'de bu gönderim, daha çok daha, kadar, benzer, gibi, çok, ise, en... gibi zarf ve edatlar yoluyla sağlanmaktadır (Coşkun, 2005). Böylelikle metin içerisinde daha önce geçen bir nesyeye ya da varlığa dair benzerlik, farklılık, azlık, çokluk gibi ilişkiler oluşturmaktadır. "Arda bir işe başladığı zaman mutlaka sonunu getirirdi fakat Burak onun kadar azimli değildi." cümlesindeki "kadar" sözcüğü Arda ve Burak arasında karşılaştırma yapmaktadır.

Eksiltili anlatım ise anlatımı güçleçtirmeden, anlam karmaşına yer vermeden ve anlam kaybı olmaksızın bazı kelimelerin ya da yapıların kullanılmaması durumudur (Coşkun, 2005; Seçkin, Arslan ve Ergenç, 2014; Yılmaz, 2012). Böylelikle gereksiz yere yapılan tekrarlardan kaçınılmış olunmaktadır. Eksiltili anlatım zamirler, sıfatlar ya da zarflar kullanılarak yapılacağı gibi isim tamlamalarının, ögelerin ve bazı söz öbeklerinin çıkarılmasıyla da gerçekleştirilebilir. Coşkun (2005), Türkçe' de bağdaşıklık içeren eksiltili anlatım durumlarını üç ana başlık altında toplamıştır. Bunlardan ilki bir öge dışında cümlenin tamamının düşürülmesi 'dir. Genellikle soru cevap tarzındaki diyaloglarda kullanılmaktadır. Örneğin “-Bu akşam maçı Ali İskender mi yönetecek? -Evet (Bu 
akşamki maçı Ali İskender yönetecek). Diğer bağdaşıklık içeren eksiltili anlatım, ortak ögelerin düşürülmesidir. Ortak öge metin içerisinde peşpeşe gelen cümlelerde aynı ögenin kullanılması durumudur ve cümledeki herhangi bir öge olabilir. Örnek olarak "Sezonun ilk ayında Beşiktaş 4, Fenerbahçe ise 1 galibiyet almıştı" cümlesinde "sezonun ilk ayı" ortak tümleç olarak, "almıştı" eylemi ise ortak yüklem olarak kullanılmıştır. Bağdaşıklık içeren eksiltili anlatım durumlarından son olarak eklerin düşürülmesi ise, cümle içinde aynı çekim ekine sahip eklerin bulunduğu sözcüklerde ortak ek bir kere kullanılıp diğerlerinde tekrar edilmemesidir. "Hızlı adımlarla gelmiş, şaşkın gözlerle etrafina bakıyordu." cümlesinde geçmiş zaman eki olan " -d1/tı" eylemlerin birinde kullanılırken diğerinde kullanılmamış ve eklerin düşürülmesiyle oluşan eksiltili bir anlatıma örnek olmuştur.

Bağdaşıklık oluşturan bir diğer öge ise değiştirimdir. Değiştirim, genel olarak bir ögenin yerini başka bir ögenin alması anlamına gelmektedir (Coşkun, 2005; Yılmaz, 2012). Değiştirim isme dayalı, fiile dayalı ve cümleye dayalı olmak üzere üç şekilde yapılmaktadır. İsme dayalı değiştirim metin içinde önceden kullanılmış bir isim yerine başka bir ifadenin kullanılmasıdır. Türkçe'de isme dayalı değiştirim genellikle "aynı, öyle, böyle" kelimeleri ile sağlanmaktadır (Coşkun, 2005). Örneğin, “-Gittiğimiz otel çok eğlenceliydi. - Bizimki de öyledi” cümlesinde "öyle" kelimesi ilk cümledeki "eğlenceli” kelimesinin yerine kullanılmıştır. Fiile dayalı değiştirimde ise değişen öge fiildir ve genellikle "öyle yapmak" ifadesi ile sağlanmaktadır. Örnek olarak "Borçlarından dolayı bir süre evden çıkmamayı düşündü ve öyle yaptı." cümlesinde “öyle yaptı” fiili "evden çıkmamak” fiilinin yerine kullanılmış ve değiştirim oluşturmuştur. Son olarak cümleye dayalı değiştirimde ise değiştirilen ögenin cümle, cümlecik ya da cümleler grubu olduğu durumlardır. Genellikle "öyle, böyle, şöyle” kelimeleri ile yapılmaktadır. "Kitap okumadan da öğrenebileceğini düşünüyordu. Bence öyle değil." cümlesinde geçen "öyle” kelimesi ilk cümlenin yerine kullanılmış ve cümleye dayalı bir değiştirim oluşturmuştur.

Yapısı itibariyle bir metni oluşturan cümleler ve paragraflar birbirleri ile ilişkili olmak durumundadır. Bu durumun oluşabilmesi için bir takım bağlama ögelerine ihityaç duyulmaktadır. Bağlama ögeleri çoğunlukla bağlaçlardan oluşurken birtakım edat ve zarflar da bu kategoriye girmektedir (Coşkun, 2005). Bu çalışmada bağlama ögeleri ekleyici, ayırt edici, zıtlık bildiren, zaman-sıralama bildiren, koşul bildiren, açıklama bildiren, örnekleme bildiren ve sebep-sonuç ilişkisi kuran bağlama ögeleri şeklinde incelenmiştir. Ekleyici bağlama ögeleri, benzer işlevlere sahip sözcükleri, sözcük gruplarını ya da metinleri birbirine bağlarken kullanılır. Başlıca ekleyici bağlama ögeleri ise; ve, ile, de, bunun yanı sıra, ilaveten, bundan başka, ayrıca vb. şeklinde sıralanabilir. Ayırt edici bağlama ögeleri ise metin içindeki iki durumdan birinin geçerli olduğu durumlarda kullanılmaktadır. Başlıca ayırt edici bağlama ögeleri ise ya da, sadece, hariç, veya, ya...ya (da) şeklinde sıralanabilir. Bir diğer bağlama ögesi de zıtlık bildiren bağlama ögesidir. Zıtlık bildiren bağlama ögeleri olumlu ve olumsuz iki durumu birbirine bağlamak için kullanılmaktadır. Genel olarak zıtlık içeren bağlama ögeleri ama, lakin, ră̆men, ancak, oysa (ki) vb. şeklindedir. Olay ve durumların öncelik-sonralık ya da eş zamanlılık ilişkisine göre birbirine bağlayan öge de zaman-sıralama bildiren bağlama ögeleridir. Sıklıkla kullanılan zaman-sıralama bildiren bağlama ögeleri önce, ilk olarak, öncelikle, sonra, en sonunda, şimdi, hemen, artık, aynı zamanda, gene, hep, yine, her zaman, bu sırada vb.şeklindedir. Koşul bildiren bağlama ögeleri ise metin içindeki durum ya da yargının diğer durumlar için bir koşul niteliği taşıması durumunda kullanılmaktadır. Başlıca kullanılan koşul bildiren bağlama ögeleri eğer...(i)se, şayet, yeter ki, yoksa, mı, takdirde, vb. şeklinde sıralanabilir. Açıklama bildiren bağlama ögeleri metindeki bir durumun ya da olayın daha iyi anlaşılmasını sağlamak için kullanılmaktadır. Yani, gerçekten, aslında, başka bir deyişle, kısacası, herhalde, sanki, zaten, açıkçası gibi ifadeler sık kullanılan açıklama bildiren ögelerdir. Metinde örnekleme yapılacağı zaman örnekleme bildiren bağlama ögeleri kullanılmaktadır. Başlıca kullanılan örnekleme bağlama ögeleri ise örneğin, mesela, ve benzeri, ve saire'dir. Son olarak bağdaşıklık oluşturan bağlama ögesi ise sebep-sonuç ilişkisi kuran bağlama ögeleridir. Bu öge öncelik ve sonralığına göre sebep-sonuç ya sonuç-sebep şeklinde olabilir. Sebep-sonuç ilişkisi kuran bağlama ögeleri, genel olarak bu nedenle, bu yüzden, dolayısıyla, öyleyse, böylece, o halde, çünkü, -si...-den,...-sinin nedeni vb kelimeler ile oluşturulmaktadır.

İştime engelli bireyler bilişsel süreçlerde akranları ile benzer fakat daha yavaş bir işleyiş sürecine sahiptirler (Schirmer, 2001). Ayrıca işitme engelli öğrencilerin sahip oldukları işitme kaybının onların alıcı dil ve ifade edici dil gelişimlerinde sınırlılıklar oluşturduğugörülmektedir (Akmeşe ve Acarlar, 2016; Vaughn, Linan- 
Thompson ve Hickman-Davis, 2003). Yaşanan bu sınırlılıklar işitme engelli öğrencilerin okuma ve yazma performanslarını da olumsuz etkilemektedir (Tüfekçioğlu, 1992). İşitme engelli öğrencilerin sözcük dağarcıklarının sınırlı olması, bununla birlikte genellikle kısa ve basit cümleleri kullanmaları ile sözdizimi becerilerinde yaşadıkları sıkıntılar onların okuma ve yazma becerilerinde problemler yaşamalarına sebep olmaktadır (Akçamete, 2003; Antia, Reed ve Kreimeyer, 2005; Erdiken, 2010; Karasu, 2004). Yapılan çalışmalarda işitme engelli bireylerin yazılı anlatım becerilerinde sıkıntılar yaşadıkları (Karasu, 2004; Kontrot, 2005; Turğut, 2012), özellikle yazılı metinlerde ana düşünceyi açıklamada, konuyu açık ve net bir şekilde ifade etme ve ayrıca metnin giriş, gelişme ve sonuç bölümlerini oluşturma ile olay sıralamasında problemler yaşadıkları görülmektedir. Ayrıca noktalama işaretleri ve eklerin kullanımında da sınırlılıkları göze çarpmaktadır (Erdiken, 2010; Heefnner veShaw, 1996). Tiryaki (2014) tarafından yapılan çalışmada işitme engelli öğrencilerin yazılı metinlerdeki sorunları incelenmiştir. Çalışmaya 5., 6., 7. ve 8. sınıfa devam etmekte olan toplam 40 ağır işitme engelli öğrenci katılmıştır. Sonuç olarak işitme engelli öğrencilerin yazım kurallarına dikkat etmeme, ekleri kullanamama, konuya ilişkin anlamsız ve karmaşık cümle kurma, noktalama işaretlerini yanlış kullanma ve paragraf oluşturamama gibi sorunlar yaşadıklarını tespit etmiştir. Karasu ve Girgin (2007) yaptıkları çalışmada, kaynaştırmadaki işitme engelli öğrencilerin yazılı anlatım beceri düzeylerini belirlemeyi amaçlamışlardır. Çalışmaya 4., 5., 6., 7. ve 8. sınıfa devam etmekte olan işitme engelli toplam 25 kaynaştırma öğrencisi katılmıştır. Araştırmanın bulgularına göre işitme engelli kaynaştırma öğrencilerinin başlık koyma, ana düşünceyi ortaya koyma, paragraf oluşturma, yazım kurallarına uyma gibi alanlarda problemler yaşadıkları görülmüştür. Bu çalışmada işitme kayıplı öğrencilerin metin özetleme ve bağdaşıklık düzeyleri akranlarıyla karşılıklı olarak incelenerek onların yazılı anlatımda yetersiz oldukları alanların daha net bir şekilde belirlenmesinin yapılacak olan eğitim ve müdahale çalışmaları için yol gösterici olacağı düşünülmektedir. Bu araştırmanın temel amacı işiten ve işitme engelli 8. sınıf öğrencilerinin özetleme becerileri ile bağdaşıklık düzeylerinin karşılıklı olarak incelenmesidir. Belirtilen bu amaç doğrultusunda aşağıda yer alan sorulara yanıt aranmıştır.

1) Öğrencilerin yaptıkları özetlerdeki özetleme puanları işiten ve işitme kayıplı öğrenciler arasında anlamlı bir farkl1lık göstermekte midir?

2) Öğrencilerin yaptıkları özetlerdeki bağdaşıklık puanları işiten ve işitme kayıplı öğrenciler arasında anlamlı bir farklılık göstermekte midir?

\section{Yöntem}

\section{Araştırma Deseni}

Sekizinci sınıfa devam etmekte olan işiten ve işitme kayıplı öğrencilerin bağdaşıklık ve özetleme becerilerini karşılaştırmalı olarak inceleyen bu çalışma, genel araştırma türlerinden betimsel araştırma yöntemlerinden neden-sonuç karşılaştırmalı modelde bir çalışmadır. Betimsel araştırma bireylerin ya da grupların özelliklerini ortaya koymayı hedefler (Büyüköztürk, 2008).

\section{Evren ve Örneklem/Çalışma Grubu}

Bu araştırmaya Ankara İli'nde bulunan iki işitme engelliler ortaokulundan 8. sınıfa devam eden 15 işitme yetersizliği olan öğrenci ve Ankara İli Mamak ilçesinde yer alan bir ortaokulun 8. sınıfına devam eden 15 normal işiten öğrenci katılmıştır. Araştırmaya katılan işitme kayıplı öğrencilerin 6'sı orta, 9'u ileri derecede işitme kayıplıdır. Ailelerden alınan bilgilere göre 10 öğrenci sağ ve sol olmak üzere çift kulakta, 5 öğrenci ise tek kulakta işitme cihazı kullanmaktadır. Öğrencilerin eğitimsel geçmişlerine bakıldığında bütün katılımcıların örgün eğitime başladıkları yaştan itibaren işitme engelliler okulunda eğitim aldıkları görülmektedir.

İşitme yetersizliği olan öğrencilerin belirlenmesinde; öğretmenleri tarafından bağımsız okuma ve yazma becerisine sahip olduğunun belirtilmesi, işitme yetersizliği dışında tanılanmış herhangi bir ek yetersizliğinin bulunmaması, el yazısının okunaklı olması ölçütleri aranmış ve bu ölçütler doğrultusunda çalışmaya işitme engelliler ortaokullarından 8'i kız, 7'si erkek olmak üzere toplam 15 işitme yetersizliği olan öğrenci dahil edilmiştir. İşiten öğrencilerin belirlenmesinde ise öğretmenleri tarafından bağımsız okuma ve yazma becerisine 
sahip olduğunun belirtilmesi, tanılanmış herhangi bir ek yetersizliğinin bulunmaması, el yazısının okunaklı olması ölçütleri aranmıştır. Bu ölçütler dahilinde araştırmaya ortaokuldan 8'i kız, 7'si erkek olmak üzere toplam 15 işiten öğrenci katılmıştır.

\section{Veri Toplama Araçları}

Öğrencilerin özetleme becerilerini değerlendirmek için önce öyküleyici metin verilmiş daha sonra özetlemeleri istenmiştir. Öğrencilerin okuması için Karasu, Girgin ve Uzuner (2013) tarafindan hazırlanan "Formel Olmayan Okuma Envanteri" kitabındaki Sel isimli öykü kullanılmıştır. Öğrencilerin yazdıkları özetlerin değerlendirilmesinde "Hikâye Edici Metinler İçin Özet Değerlendirme Formu" kullanılmış ve özet metinlerdeki bağdaşıklık araçlarını ne kadar sıklıkta kullandıklarını belirlemek için "Bağdaşıklık Düzeyi Değerlendirme Ölçeği” kullanılmıştır. Aşağıda verilerin toplanmasında kullanılan araçlara ilişkin açıklamalara yer verilmiştir.

Öyküleyici metin. Araştırmada Karasu ve diğerleri (2013) tarafindan hazırlanan "Formel Olmayan Okuma Envanteri" kitabının A formunda bulunan 5. sınıf düzeyinde yer alan "Sel" metni araştırmada kullanılmıştır.

Hikaye edici metinler için özet değerlendirme formu. Öğrencilerin özetlerini değerlendirmek amaciyla Bulut (2013) tarafından geliştirilen "Hikâye Edici Metinler İçin Özet Değerlendirme Formu" kullanılmıștır. Bu forma ilişkin hesaplanan Kapsam Geçerlik İndeksi 0.93’tür. Özet değerlendirme formlarının güvenirliği için iki araştırmacı 50 özeti değerlendirmiş ve araştırmacıların sonuçları arasındaki korelasyon katsayısı $(r=0.82)$ olarak hesaplanmıștır. Değerlendirme formu içerik, biçim, dil ve anlatım boyutu ve hikaye edici metin yapısı boyutu olmak üzere toplam dört alt boyuttan oluşmaktadır. İçerik boyutu altı madde, biçim boyutu dört madde, dil ve anlatım boyutu altı madde, hikaye edici metin yapısı boyutu yedi madde olmak üzere toplamda 23 maddeden oluşmaktadır. Değerlendirme aracındaki her bir maddeyi puanlarken yetersiz ise 0 puan, kısmen yeterli ise 1 , yeterli ise 2 puan verilmiş ve her bir maddeye ilişkin gereken puanlama ölçütleri tanımlanmıştır. Bu formda bulunan içerik boyutunda yer alan "özet yazarken özetleme stratejileri” maddesi amacımız içerisinde olmadığ için puanlamaya dahil edilmemiştir.

Bağdaşıklık düzeyi değerlendirme ölçeği. Öğrencilerin özetlerinde bağdaşıklık kullanım düzeyini tespit etmek amacıyla Coşkun (2005) tarafından geliştirilen bağdaşıklık araçlarının sıklığına göre tespit etmeyi amaçlayan "Bağdaşıklık Düzeyi Değerlendirme Ölçeği" kullanılmıştır. Değerlendirme ölçeğinde gönderim, eksiltili anlatım, değiştirim, bağlama ögeleri ve kelime bağdaşıklığı olmak üzere beş boyut bulunmaktadır. Beş boyuttan biri olan kelime bağdaşıklığı ayrıntılı bir çalışma gerektirdiği ve bu çalışmanın kapsamında yer almadığı için araştırmanın dışında tutulmuştur.

\section{Veri Toplama ve Analizi/Uygulama}

Araştırma verileri Mayıs 2017 tarihinde toplanmıştır. Öğrencilere kendi sınıflarında grup olarak öyküleyici metin "Sel" verilmiş, sessiz olarak en az iki kez okumaları istenmiş ve daha sonra metin toplanmış ve "Okuduğunuz metni özetleyin." yönergesi verilerek yazılı olarak özetlemeleri istenmiş̧ir. İ şitme kayıplı öğrenciler için yönergeler işaret dili ile birlikte verilmiştir. Metnin yazılı olarak özetlenebilmesi için öğrencilere boş kâğıt dağıtılmış ve özetleme sürecinde öğrencilere herhangi bir şekilde yardım edilmemiştir. Öğrencilerin yazılı ürünleri bir ders saati sonunda toplanmıştır.

Araştırmanın amaçları doğrultusunda iki istatistik yöntemi kullanılmıştır. İlk olarak öğrencilerin özetleri ve bağdaşıklık düzeylerini belirlemek için betimsel analiz yapılmıştır. İkinci olarak gruplar arasındaki farklılı̆g belirlemek amacıyla İlişkisiz Ölçümler İçin Mann Whitney U Testi kullanılmıştır.

\section{Puanlayıcılararası Güvenirlik}

Araştırmada öğrencilerin özetleme becerilerinin ve bağdaşıklık düzeylerinin değerlendirilmesi güvenirlik çalışması için puanlayıcılararası güvenirlik hesaplaması yapılmıştır. Görüş birliği puanı, görüş birliği ve görüş ayrılığı toplamına bölünüp 100 ile çarpılarak güvenirlik sayısı hesaplanmıştır. Değerlendirmeler ikinci araştırmacı 
ve Türkçe alanında çalışan bir uzman tarafından hesaplanmış ve güvenirlik ölçütü olarak .80 ve üzeri kabul edilmiştir. Bağdaşıklık düzeyi için yapılan değerlendirmeler için güvenirlik katsayıları gönderim için .98, eksiltili anlatım için .98, değiştirim için .99, bağlama ögeleri için .99 bulunmuştur. Özetleme becerileri için bulunan güvenirlik katsayıları ise içerik boyutu .92, biçim boyutu için .94, dil ve anlatım boyutu için .96 , hikaye edici metin yapısı için .91'dir.

\section{Bulgular}

\section{Öğrencilerin Yaptıkları Özetlerdeki Özetleme Puanlarının İşitme Durumuna Göre Karşılaştırılmasına İlişkin Bulgular}

Öğrencilerin özetleme puanlarını değerlendirmek için içerik toplam puanları, biçim toplam puanları, dil ve anlatım toplam puanları, metin yapısı toplam puanları ve özetleme toplam puanları aritmetik ortalaması, standart sapması, ortanca, çarpıklık ve basıklık değerleri aşağıdaki tabloda (Tablo 1) verilmiştir. Öğrencilerin özetleme puanlarının farklılaşıp farklılaşmadığı sorusu ise Mann Whitney U Testi kullanılarak yanıtlanmıştır.

Tablo 1

Öğrencilerin Özetleme Puanlarına İlişkin Betimsel İstatistikler ve Mann Whitney U Testi Sonuçları

\begin{tabular}{|c|c|c|c|c|c|c|c|c|c|c|}
\hline Özetleme Bec. & Grup & $\mathbf{n}$ & $\mathbf{X}$ & Ortanca & SS & Çarp. & Bas. & Sira ort. & $\mathbf{z}$ & $\mathbf{U}$ \\
\hline \multirow{2}{*}{ İçerik } & İşiten & 15 & 6.46 & 6.00 & 1.76 & .24 & .36 & 22.87 & - & \multirow{2}{*}{$2.00 *$} \\
\hline & İşitme Kayıplı & 15 & 1.73 & 2.00 & 1.16 & -.65 & -.97 & 8.13 & 4.64 & \\
\hline \multirow{2}{*}{ Biçim } & İşiten & 15 & 4.26 & 4.00 & .88 & .83 & .52 & 22.57 & - & \multirow{2}{*}{$6.50 *$} \\
\hline & İşitme Kayıplı & 15 & 1.13 & 1.00 & 1.12 & 1.09 & 1.57 & 8.43 & 4.50 & \\
\hline \multirow{2}{*}{ Dil ve Anlatım } & İşiten & 15 & 7,40 & 7.00 & 1.76 & .10 & -.44 & 22.97 & - & \multirow{2}{*}{$.50 *$} \\
\hline & İşitme Kayıplı & 15 & 1.40 & 1.00 & 1.24 & .65 & -.32 & 8.03 & 4.67 & \\
\hline \multirow{2}{*}{ Metin yap1s1 } & İşiten & 15 & 9 & 8.00 & 2.23 & 1.63 & 1.97 & 23.00 & - & \multirow{2}{*}{$.00^{*}$} \\
\hline & İşitme Kayıplı & 15 & 2.93 & 3.00 & 2.01 & .10 & -1.15 & 8.00 & 4.69 & \\
\hline \multirow{2}{*}{ Özetleme toplam } & İşiten & 15 & 27.3 & 26.00 & 5.35 & 1.15 & .96 & 23.00 & - & \multirow{2}{*}{$.00^{*}$} \\
\hline & İşitme Kayıplı & 15 & 7.2 & 6.00 & 4.14 & .58 & -.64 & 8.00 & 4.67 & \\
\hline
\end{tabular}

Yapılan analiz sonucunda özetlemenin içerik, biçim, dil ve anlatım, metin yapısı alt boyutlarında ve özetleme toplam puanda işitme yetersizliği olan öğrenciler ve işiten öğrenciler arasında anlamlı bir fark bulunmuştur (Tablo 1). İşiten öğrenciler özetleme becerisinin alt boyutlarına ve özetleme becerisi toplam puanlarına göre işitme yetersizliği olan öğrencilerden daha yüksektir.

\section{Öğrencilerin Yaptıkları Özetlerdeki Bağdaşıklık Düzeylerinin İşitme Durumuna Göre Karşılaştırılmașına İlişkin Bulgular}

Öğrencilerin bağdaşıklık puanlarını değerlendirmek için gönderim toplam puanları, eksiltili anlatım toplam puanları, değiştirim toplam puanları, bağlama ögeleri toplam puanları ve bağdaşıklık düzeyi toplam puanları aritmetik ortalaması, standart sapması, ortanca, çarpıklık ve basıklık değerleri aşağıdaki tabloda (Tablo 2) verilmiştir. Öğrencilerin bağdaşıklık puanlarının farklılaşıp farklılaşmadığı sorusu ise Mann Whitney U Testi kullanılarak yanıtlanmıştır.

Tablo 2 
Öğrencilerin Bă̆daşıkllk Düzeylerine İlişkin Betimsel İstatistikler ve Mann Whitney U Testi Sonuçları

\begin{tabular}{|c|c|c|c|c|c|c|c|c|c|c|}
\hline Bağdaşıklık Düzeyi & Grup & $\mathbf{n}$ & $X$ & Ortanca & SS & Çarp. & Bas. & Sira ort. & $\mathbf{z}$ & $\mathbf{U}$ \\
\hline \multirow{2}{*}{ Gönderim } & İşiten & 15 & 6.80 & 7.00 & 1.69 & -.24 & -.97 & 23.00 & \multirow{2}{*}{-4.80} & \multirow[b]{2}{*}{$.00 *$} \\
\hline & İşitme Kayıplı & 15 & .73 & 1.00 & .45 & -1.17 & -.73 & 8.00 & & \\
\hline \multirow{2}{*}{ Eksiltili Anlatım } & İşiten & 15 & 4.93 & 5.00 & 2.34 & .74 & .50 & 22.80 & \multirow{2}{*}{-4.67} & \multirow{2}{*}{$3.00 *$} \\
\hline & İşitme Kayıplı & 15 & 1.00 & 1.00 & .53 & .00 & 1.61 & 8.20 & & \\
\hline \multirow{2}{*}{ Değiştirim } & İşiten & 15 & .13 & .00 & .35 & 2.40 & 4.34 & 16.50 & \multirow{2}{*}{-1.43} & \multirow{2}{*}{97.50} \\
\hline & İşitme Kayıplı & 15 & .00 & .00 & .00 & - & - & 14.50 & & \\
\hline \multirow{2}{*}{ Bağlama Öğeleri } & İşiten & 15 & 9.66 & .10 & 3.17 & .66 & -.32 & 23.00 & \multirow{2}{*}{-4.76} & \multirow{2}{*}{$.00^{*}$} \\
\hline & İşitme Kayıplı & 15 & .40 & .00 & .63 & 1.40 & 1.26 & 8.00 & & \\
\hline \multirow{2}{*}{ Bağdaşıklık Top. } & İşiten & 15 & 21.60 & 20.00 & 5.72 & 1.07 & .62 & 23.00 & \multirow{2}{*}{-4.78} & \multirow{2}{*}{$.00^{*}$} \\
\hline & İşitme Kayıplı & 15 & 2.13 & 2.00 & .83 & 1.43 & 2.50 & 8.00 & & \\
\hline
\end{tabular}

Yapılan analiz sonucunda bağdaşıklık düzeyinin gönderim, eksiltili anlatım, bağlama ögeleri alt boyutlarında ve bağdaşıklık düzeyi toplam puanlarında işitme yetersizliği olan öğrenciler ve işiten öğrenciler arasında anlamlı bir fark bulunmuştur (Tablo 2). Bağdaşıklık düzeyinin değiştirim alt boyutunda işiten ve işitme yetersizliği olan öğrenciler arasında anlamlı bir fark bulunmamıştır. İşiten öğrencilerin bağdaşıklık düzeyi gönderim, eksiltili anlatım, bağlama öğeleri alt boyut puanları ve bağdaşıklık toplam puanları işitme yetersizliği olan öğrencilere göre daha yüksektir. Ayrıca hem işiten hem de işitme yetersizliği olan öğrencilerin özetlerinde değiştirim öğelerini kullanmadıkları görülmektedir.

\section{Tartışma ve Sonuç}

Bu çalışmada Ankara İli’nde 8. sınıfa devam işiten ve işitme yetersizliği olan öğrencilerin özetleme ve bağdaşıklık düzeylerinin karşılaştırmalı olarak incelenmesi amaçlanmıştır. Bu çalışmadan elde edilen bulgular ilgili alanyazın kapsamında araştırma soruları dikkate alınarak aşağıda açıklanmıştır.

\section{Öğrencilerin Yaptıkları Özetlerdeki Özetleme Puanları İşitme Durumuna Göre Anlamlı Bir Farklılık Göstermekte midir?}

$\mathrm{Bu}$ araștırmanın sonuçları işiten ve ișitme yetersizliği olan öğrencilerin özetleme becerileri arasında anlamlı bir farklılık olduğunu göstermektedir. Yapılan analiz sonucunda işitme yetersizliği olan öğrencilerin özetleme becerileri toplam puanları ve özetleme becerilerinin alt boyutlarına ilişkin alınan puanları işiten öğrencilere göre zayıf olduğu görülmektedir. İșitme yetersizliği olan öğrencilerin özetleme becerilerini kullandıkları fakat kullanım düzeylerinin işiten akranlarına göre daha düşük düzeyde olduğu görülmektedir. Özetlemenin içerik boyutuna bakıldığında işitme yetersizliği olan öğrencilerin işiten öğrencilere göre düşük performans gösterdikleri görülmektedir. Bir diğer alt boyut olan biçim boyutuna baktığımızda ise işitme yetersizliği olan öğrencilerin işiten öğrencilere göre daha düşük düzeyde performans sergilemişlerdir. İşitme yetersizliği olan öğrencilerin özetlerine bakıldığına öğrencilerin öykü ile ilişkili bir konu yazdıkları fakat özette bir başlık yazmadıkları, ana fikri belirtmedikleri, sayfayı düzenli kullanmada zorlandıkları görülmektedir. Alanyazında bu bulguya paralel olarak işitme yetersizliği olan öğrencilerin başlık, anlatım düzeni, anlatım zenginliği ve yazım kurallarına uygunluk becerilerinde çeşitli becerileri kullanmakta zorlandıkları ve bu yüzden yazılı anlatımlarının işiten yaşıtlarına göre geride kaldıkları belirtilmektedir (Antia ve diğ., 2005; Girgin, 2002; Gormley ve Sarachan-Deily,1987; Heefner ve Shaw, 1996; Karasu, 2004; Peterson, 1986a, 1986bb; YoshinagaItano ve Downey, 1992). Üçüncü alt boyut olan dil ve anlatım boyutuna bakıldığında işitme yetersizliği olan öğrencilerin, işiten öğrencilere göre düşük performans gösterdikleri görülmektedir. İşitme yetersizliği olan öğrenciler işiten öğrencilerle karşılaştırıldığında özetlerindeki cümlelerde zaman ve kip uyumu olmadığı ve birçoğunda geçmiş zaman ifadeleri kullanıldığı, özetin içeriğinde anlatım bozukluklarının olduğu ve alanyazınla benzer sonuçlar ortaya çıktığı görülmüştür (Klecan-Aker ve Blondeau, 1990; Peterson, 1986a, 1986b; YoshinagaItano ve Downey, 1996). Okullarda kullanılan öğretim yöntemlerine bakıldığında öğrencilere sıklıkla belli 
kalıpların ve kuralların öğretilmesinden veya ezberletilmesinden kaynaklı olarak, öğrenciler yeterince muhakeme yapamıyor ve dilbilgisi becerilerinin kullanımında da zorluk yaşıyor olabilirler. İşitme yetersizliği olan ögrrencilerin özetlerine bakıldığında verilen öykülerin metin yapısı (sahne, karakterler, problem) ile ilgili bilgiye işiten öğrenciler kadar iyi düzeyde olmasa da öykü yapısı bilgisine sahip oldukları görülmektedir. Bu öğrencilerin özetlerinde verilen öyküye ilişkin yer, karakter, problem bilgisine yer verdikleri, fakat yazılan özetteki bilgilerin özet metin yapısı için istenilen yeterlilikte olmadığı görülmüştür. Bu sonuçlar işitme yetersizliği olan öğrencilerin hikayenin yapısını oluşturan bilgilerin nelerden oluşması gerektiğini, bu bilgileri nasıl bulacaklarını ve bunu bir özet olarak yazarken nasıl organize edip yazılı bir metine dönüştüreceklerini bilmediklerini göstermektedir.

İşitme yetersizliği olan ve işiten öğrenciler arasında çıkan bu farklılıklara ilişkin yapılabilecek ilk açıklama, işitme yetersizliği olan öğrencilerin işiten öğrencilere göre okudukları metni özetlerken metindeki bilgilerden önemli ve önemsiz olanı ayırt etmede zorluk yaşamış olabilecekleridir (Brown ve Day, 1983; Day, 1980; Garner, 1982; Peterson, 1986a, 1986b; Peterson ve French, 1988). Özetleme yaparken önemsiz bilgiyi metinden çıkarmak önemli bilgilerin ne olduğuna karar verip daha sonra onu yazıya dahil etmeye göre daha kolay bir beceridir. Çünkü önemli bilgilerin ne olduğuna karar verirken cümleler veya paragraflar arasındaki düşünceleri analiz edip yorumlama yapmak ve karar vermek gerekmektedir. Yoshinaga-Itano, Snyder, Mayberry (1996a, 1996b) tarafından yapılan çalışmalarda, çeşitli eğitim ortamlarında bulunan işitme yetersizliği olan bireylerin yazdıkları metinler incelenmiş ve bu bireylerin metinlerde ana fikirleri verdikleri fakat ayrıntılı bilgilere yer vermedikleri görülmüştür. Peterson (1983) tarafından yapılan çalışmada, 13 işitme yetersizliği olan ve 14 işiten öğrenciye beşinci sınıf düzeyinde metinler verilerek özetleme becerisi incelenmiştir. İşiten öğrenciler ile işitme yetersizliği olan öğrenciler metinden önemsiz bilgiyi çıkarmada benzer performans sergilemişlerdir. Fakat işiten öğrencilerin konu cümlelerini ve ana fikri çıkarmada işitme yetersizliği olan öğrencilere daha iyi performans gösterdikleri bulunmuştur. Peterson ve French (1988), 30 işiten ve işitme yetersizliği olan öğrencinin katıldiğ çalışmada öğrencilerin özetleme becerilerini incelemişlerdir. Araştırmada işitme yetersizliği olan öğrencilerin önemli bilgileri ayırt etmede ve ana fikiri belirtmede işiten öğrencilere göre zayıf performans gösterdikleri görülmüştür. Bu çalışmanın sonuçları işitme yetersizliği olan öğrencilerin verilen öykünün özetini yaparken metindeki önemli bilgilerin ne olduğuna karar verebilme becerisi açısından işiten öğrenciler kadar yeterli düzeyde olmadıklarını ve bu sonuçların da ilgili alan yazınla tutarlı olduğunu göstermektedir. Özkan (2010) tarafından yapılan çalışmada, 3., 4. ve 5. sınıfa devam eden işitme kayıplı öğrenciler ile işiten öğrencilerin okuduklarını anlatma becerileri incelenmiş ve işiten öğrencilerin metindeki karakterler, ana olaylar ve detay bölümlerinden daha yüksek puan aldıkları ve okuduğunu anlama becerilerinde daha başarılı oldukları bulunmuştur. Bu durumun nedeni işitme kayıplı bireylerin işitsel girdi eksikliğinden dolayı geçmişe dayalı bilgi ve becerilerinde işiten bireylere göre daha yetersiz olmaları şeklinde açıklanmıştır.

İkinci açıklama olarak işitme yetersizliği olan öğrencilerin üstbilişsel bilgilerindeki eksikliklerden dolay1 özetleme yaparken işiten öğrencilere göre daha düşük performans göstermiş olabilirler (Akamatsu, 1988; Alvermann, 1982; Benedict, Rivera ve Antia, 2014; Hiebert, Englert ve Brennan, 1983, Marschark ve Wauters, 2008; Peterson ve French, 1988, Strassman, 1997). Marschark, Lang ve Albertini (2002), işitme yetersizliği olan öğrencilerin üstbilişsel bilgilerini yanlış ya da uygun yerde daha az kullandıklarını ifade etmişlerdir. Anlamayı kolaylaştırmak için strateji kullanırken önemli olan bildiğimiz ve anladığımız şeyin ne olduğu hakkında farkındalığımızın olmasıdır. Bu bakış açısıyla Strassman (1997), işitme yetersizliği olan öğrencilerin okudukları metinde neyi anlayıp anlamadıkları konusunda kendilerini değerlendirmede yetersiz olduklarını belirtmektedir. Bu çalışmada işitme yetersizliği olan öğrencilerin okudukları metni yeniden oluşturmada ve metni yorumlamada güçlük yaşadıkları görülmüştür. Bir başka deyişle iyi bir özetleme için gerekli olan yeniden düzenleme becerilerini işiten öğrenciler kadar yeterli düzeyde kullanamadıkları için işitme yetersizliği olan öğrencilerin bu konuda yetersiz oldukları düşünülmektedir. Üçüncü olarak ise özetleme becerisi metni işlemleme ile ilişkili olduğu için işitme yetersizliği olan öğrenciler işiten öğrencilere göre metni daha düşük düzeyde anlamış olabilirler (Peterson ve French, 1988). İşitme yetersizliği olan öğrenciler özeti oluştururken hikâyedeki parçalar ile bütün arasında ilişkileri kurmakta zorlandıkları için özetler daha farklı sunulmuş olabilir. 


\section{Öğrencilerin Yaptıkları Özetlerdeki Bağdaşıklık Düzeyleri İşitme Durumuna Göre Anlamlı Bir Farklılık Göstermekte midir?}

$\mathrm{Bu}$ araştırmanın sonuçları işiten ve işitme yetersizliği olan öğrencilerin bağdaşıklık düzeyleri arasında anlamlı bir farklılık olduğunu göstermektedir. İşiten öğrenciler gönderim ögelerini, eksiltili anlatım ve bağlama ögelerinin kullanımında işitme yetersizliği olan öğrencilere göre daha başarılıdır. Öğrencilerin yazdıkları özetlere bakıldığında işiten öğrencilerin işitme yetersizliği olan öğrencilere göre bağlama ögelerini daha sık kullandıkları ve buna bağlı olarak karmaşık cümleler kurmuş oldukları görülmektedir. İşitme yetersizliği olan öğrencilerin yazdıkları öyküleri inceleyen araştırmalara bakıldığında bu öğrencilerin bağlama ögelerini kullanım sıklıklarının düşük olduğu görülmektedir (Burman, Evans, Nunes ve Bell, 2008; Erdiken, 2010; Karasu ve Girgin, 2007; Klecan-Aker ve Blondeau, 1990; Yoshinaga-Itano ve Downey, 1996). Hem işiten hem de işitme yetersizliği olan öğrencilerin değiştirim ögelerini kullanmadıkları görülmüştür. Bu bulgunun hem ulusal hem de uluslararası alanyazınla tutarlı olduğu görülmektedir (Bae, 2001; Maxwell ve Falick, 1992; Ramadan, 2003). İşitme yetersizliği olan öğrencilerin düşük performans göstermelerinin nedenlerine ilişkin yapılabilecek ilk açılama öğrencilerin, metin içi bağlantıların oluşturulmasında çok dikkatsiz davrandıkları ve buna bağlı olarak bağdaşıklık araçlarından yararlanmakta yeterince başarılı olamadıklarıdır. İkinci açıklama ise öğrencilerin yazdıkları metinler kısa olduğu için bağdaşıklık araçları kullanım sıklıklarının düşük çıkmış olabildiği şeklindedir. Üçüncü açıklama da bağdaşıklık araçlarının kullanımının dil gelişimi ile yakından ilişkili olduğudur (Coşkun, 2005; Maxwell ve Falick, 1992). Varonis ve Gass (1985), işitme yetersizliği olan öğrencilerin farklı bir dilde okuma yapan bireylerin yaptığ gibi önceki bilgi ve deneyimleri ile "metinin ne demek istediğini”" tahmin etmeye çalışarak bir sonuca vardıklarını ifade etmektedir. Crosson ve Geers (2001), sekiz ve dokuz yaşlarındaki işitme kayıplı öğrencilerin yazılı öykülerini incelemiştir. İşitme kayıplı çocukların daha basit düzeyde sözdizimsel cümle kurduklarını ve yazılı öykülerin sıklıkla eksik ve kısa cümlelerden oluştuğunu, ayrıca yazma becerisi için gerekli olan zarflar ve bağlaçların istenen düzeyde olmadığını belirtmişlerdir. Alanyazındaki bu çalışmaların sonuçlarından yola çıkarak, işitme yetersizliği olan öğrencilerin işiten öğrenciler kadar dil deneyimine sahip olmadıkları düşünüldüğünde, bu araştırmaya katılan 8. sınıf işitme yetersizliği olan öğrencilerin dil becerilerinin işiten akranları ile benzer düzeyde olmadığıve bu nedenle bağdaşıklık araçlarının kullanım sayısının az olduğu düşünülmektedir.

İşitme yetersizliği olan bireylerin düşüncelerini yazıya aktarırken bağdaşıklık becerilerini aktarmada güçlük yaşadıkları görülmüştür. Bu öğrencilerin yazılı metinde yer alan cümlelerin içinde ve cümleler arasında bağdaşıklık araçlarını kullanım sıklıklarının yetersiz düzeyde olduğunu gösteren araştırmalar bulunmaktadır (de Villiers, 1991; Maxwell ve Falick, 1992; Yoshinaga-Itano ve diğ., 1996b). Yoshinaga-Itano ve diğerleri (1996a, 1196b) tarafından yapılan çalışmalarda, işitme yetersizliği olan bireylerin yazdıkları metinde cümleleri birbirine bağlamak için az sayıda bağdaşıklık araçlarına yer verdikleri görülmüştür. Maxwell ve Falick (1992), ayrı okulda öğrenim gören dördüncü ve sekizinci sınıftaki işitme yetersizliği olan bireyler ile işiten bireylerin yazdıkları metinleri incelemişlerdir. Hem işiten hem de işitme yetersizliği olan bireylerin sınıf düzeyleri arttıkça metinde kullandıkları bağdaşıklık ögelerinde artış olduğu bulunmasına rağmen işitme yetersizliği olan bireylerin zamirleri kullanmadıkları, bunun yerine kelime tekrarı yaptıkları bulunmuştur. Ayrıca işitme yetersizliği olan öğrencilerin bağlama ögeleri kullanım sıklıklarına bakıldığında, her iki sınıf düzeyinde de işiten öğrencilere göre daha az kullandıkları ortaya çıkmıştır. İşiten ve işitme yetersizliği olan öğrencilerin değiştirim ögesi kullanımları çok düşük olmasına rağmen iki grup arasında anlamlı bir fark bulunmuştur. Özetle işitme yetersizliği olan öğrencilerin bağdaşıklık araçlarını çok temel düzeyde kullandıklarını, bunun nedeninin işitme yetersizliği olan öğrencilerin sınırlı sözcük dağarcıklarından kaynaklanabileceğini açıklamışlardır. Marschark, Mouradian ve Hallas (1994), işitme yetersizliği olan bireylerin işiten akranları kadar bağdaşıklık araçlarını uygun şekilde kullanabildiklerini fakat akıcı yazma ile ilişkili olan sözdizimi becerilerinde ve sözcük dağarcığında sınırlılıkları olduğunu bulmuşlardır. Singer ve Bashir (2004), işitme yetersizliği olan öğrencilerin bilişsel farklılıklarının yazma sürecinde bağdaşıklık araçlarını kullanımlarını ve metin bütünlügünü etkileyebileceğini ifade etmektedirler. Antia ve diğerleri (2005), işitme yetersizliği olan öğrencilerin yazma sürecinde yaşadıkları problemlerin, aldıkları eğitimin yetersiz olmasından ya da yanlış öğretim yaklaşımlarından kaynaklandığını belirtmektedirler. İşitme yetersizliği 
olan öğrencilere sadece temel cümle yapılarını öğretmek, onların bağdaşıklık araçlarının anlamlarını öğrenmelerine ve kullanmalarına engel olabilir.

Bu çalışmanın bulguları, işitme yetersizliği olan öğrencilerin okuma ve yazma becerisi açısından önemli bilgileri kullanmayı ve tanımlamayı gerektiren görevlerle biraz daha fazla karşılaşmasına ve bunların sistemli bir biçimde öğretilmesine ihtiyaç duyulduğunu göstermektedir. Örneğin öğretmenler sınıfta metin içerisindeki paragraflar arasında veya paragraf içinde benzer fikirleri çıkartma, metni anlamsal olarak tekrar düzenleme gibi etkinlikler yapabilir. Özetleme becerisinde başarılı olmak için işitme yetersizliği olan öğrenciler okuma görevinde daha aktif ve bilinçli rol almalıdır. Öğrencilere özetleme becerilerinin alt boyutları öğretilmeli veya bu beceriler geliştirilmelidir. Bu durum öğrencilerin sadece metindeki önemli bilgilerin farkındalığı ile ilgili değil aynı zamanda bu bilgileri yazıya nasıl dahil edebileceklerini de kapsamalıdır. Öğrencilere kazandırılması planlanan amaçlara ulaşabilmek için etkinliklerin öğrencilerin dil ve bilgi düzeyine uygun hazırlanması, kullanılan materyallerin öğrencilerin bireysel özelliklerine ilişkin olarak çeşitlendirilmesi, son olarak da öğrencilerin sistematik olarak değerlendirilerek ihtiyaçlarına yönelik eğitim programının düzenlenmesi gerekmektedir. Ayrıca işitme yetersizliği olan öğrenciler ile bireysel olarak yapılan yazım becerisinin geliştirilmesine ilişkin etkinliklerin onların yazma becerilerinin gelişimine katkı sağladığı alanyazındaki çalışmalarla kanıtlanmıştır (Gormley ve Sarachan-Deily,1987; Karasu, 2014; Schirmer, 2000). Son olarak bu çalışma, öğrencilerin eğitim sürecinin başından beri en çok karşılaştıkları bir metin türü olan öyküleyici metin ile yapılmıştır. Buna rağmen öğrencilerin yazdıkları özetlerin özetleme becerileri ve bağdaşıklık düzeyi açısından çok zayıf olması bize bu konuda daha fazla eğitime ve araştırmaya ihtiyaç duyulduğunu göstermektedir. İşitme yetersizliği olan öğrencilerin ilgisini çekecek, onların yaşam deneyimleri ile ilişkili bir yazma programı hem özetleme hem de bağdaşıklık araçlarını kullanma becerilerini geliştirmeye yardımcı olabilir.

Bu çalışma Ankara Milli Eğitim Bakanlığı’na bağlı iki işitme engelliler ortaokulunun ve bir ortaokulun 8. sınıf öğrencileri ile sınırlıdır. Öğrencilerin özetleme becerilerini değerlendirmek için kullanılan araçlar bir öyküleyici metin ve yazılan özetleri değerlendirme amacıyla özet değerlendirme aracı ve bağdaşıklık düzeyi değerlendirme aracı ile sınırlıdır. Bu çalışmada sadece özetleme stratejisi ele alındığı için ileriki araştırmalarda işitme kayıplı ve işiten öğrencilerin diğer okuduğunu anlama stratejilerini kullanma durumları ve bunlar arasındaki ilişkilere yönelik araştırmalar yapılabilir. Araştırmalar sınıf düzeyinin artması ile birlikte özet yazmada daha başarılı olduklarını açıklamaktadır (Anderson ve diğ,19918). Dolayısıyla özetleyicinin yaşının özet yazmayı etkileyen bir değişken olduğu düşündüldüğünde daha üst sınıf öğrencilerle farklı çalışmalar yapılabilir. 


\section{Kaynaklar}

Akamatsu, C. T. (1988). Instruction in text structure: Metacognitive strategy instruction for literacy development in deaf students. ACEHI Journal, 14(1), 13-32.

Akçamete, G. (2003). İşitme yetersizliği olan çocuklar. A. Ataman (Ed.), Özel gereksinimli çocuklar ve özel eğitime giriş (4. Bask1) içinde (pp. 193-246) [Children with special needs and introduction to special education]. Ankara. Gündüz Eğitim ve Yayıncılık.

Akmese, P. P., \& Acarlar, F. (2016). Using narrative to investigate language skills of children who are deaf and with hard of hearing. Educational Research and Reviews, 11(15), 1367-1381.

Aktaş, E., \& Bayram, B. (2017). Ortaokul öğrencilerinin okuduğunu anlamada özetleme stratejilerini kullanma becerilerinin değerlendirilmesi [Evaluation of the usage skills of summarizing strategies secondary school students]. Uluslararası Türkçe Edebiyat Kültür Eğitim Dergisi, 6(1), 346-360.

Akyol, H. (2008). Türkçe ögretim yöntemleri [Turkish teaching methods]. Ankara: Kök Yayıncılık.

Alvermann, D. E. (1982). Restructuring text facilitates written recall of main ideas. Journal of Reading, 25(8) 754758.

Anderson, V., Hidi, S., \& Babadoğan, C. (1991). Özetlemenin öğrencilere öğretimi [Teaching summary]. Ankara Üniversitesi Eğitim Bilimleri Fakültesi Dergisi, 24(2), 587-594.

Antia, S. D., Reed, S., \& Kreimeyer, K. H. (2005). Written language of deaf and hard-of-hearing students in public schools. Journal of Deaf Studies and DeafEducation, 10(3), 244-255.

Arslan-Erol, H. (2010). Kilis ağzında dönüşlülük zamiri [The reflexive pronoun in Kilis dialect]. Gaziantep Üniversitesi Sosyal Bilimler Dergisi, 9(2), 345-356.

Bae, J. (2001). Cohesion and coherence in children's written English: Immersion and English-only classes. Issues in Applied Linguistics, 12(1), 51-88.

Belet, Ş. D., \& Yaşar, Ş. (2007). Öğrenme stratejilerinin okuduğunu anlama ve yazma becerileri ile Türkçe dersine ilişkin tutumlara etkisi [Effectiveness of learning strategies over reading comprehension, writing skills and learners' atitudes towards Turkish course]. Eğitimde Kuram ve Uygulama, 3(1), 69-86.

Benedict, K. M., Rivera, M. C., \& Antia, S. D. (2014). Instruction in metacognitive strategies to increase deaf and hard-of-hearing students' reading comprehension. Journal of deaf studies and deaf education, 20(1), 115 .

Beyreli, L., Çetindağ, Z., \& A. Celepoğlu. (2005). Yazılı ve sözlü anlatım [Written and oral expression]. Ankara. Pegem A Yayıncılik.

Braxton, D. M. (2009). The effects of two summarization strategies using expository text on the reading comprehension and summary writing of fourth-and fifth-grade students in an urban, title 1 school (Doctoral dissertation, University of Maryland). Retrieved from http://search.proquest.com/

Brown, A. L., \& Day, J. D. (1983). Macrorules for summarizing texts: The development of expertise. Journal of Verbal Learning and Verbal Behavior, 22(1), 1-14.

Bulut, P. (2013). İlköğretim 5. sinıf ögrencileri ve ögretmenlerinin özetleme stratejilerinin dĕgerlendirilmesi: Türkçe dersi örneği [The evaluation of summarizing strategies of the primary school 5th grade students and teachers: Turkish lesson example] (Unpublished master's thesis, Gazi University, Institute of Educational Sciences, Ankara, Turkey). Retrieved from http://tez.yok.gov.tr/Ulusal Tez Merkezi. (Thesis Number 328866) 
Burman, D., Evans, D., Nunes, T., \& Bell, D. (2008). Assessing deaf children's writing in primary school: Grammar and story development. Deafness \& Education International, 10(2), 93-110.

Büyüköztürk, Ş. (2008). Veri analizi el kitabı: Istatistik, araştırma deseni, SPSS uygulamalarl ve yorum. Ankara: PEGEM Akademi.

Calhoon, M. B. (2005). Effects of a peer-mediated phonological skill and reading comprehension program on reading skill acquisition for middle school students with reading disabilities. Journal of Learning Disabilities, 38(5), 424-433.

Calp, M. (2010). Özel ĕgitim alanı olarak Türkçe ögretimi [Teaching Turkish as a special education area]. Ankara: Nobel Akademik Yayıncılık.

Cavkaytar, S. (2010). Dengeli okuma yazma yaklaşımının Türkçe öğretiminde uygulanması: İlköğretim 5. sınıfta bir eylem araştırması [Application of balanced literacy in Turkish education: An action research with 5th grade] (Unpublished doktarate thesis, Anadolu University, Institute of Educational Sciences, Eskisehir, Turkey). Retrieved from http://tez.yok.gov.tr/UlusalTezMerkezi (Thesis Number 249400)

Coşkun, E. (2005). Illköğretim öğrencilerinin öyküleyici anlatımlarında bağdaşıklık, tutarlılık ve metin elementleri [Cohesion, coherence and text elements in narrative texts of primary school students] (Unpublished doktarate thesis, Gazi University, Institute of Educational Sciences, Ankara, Turkey). Retrieved from http://tez.yok.gov.tr/UlusalTezMerkezi. (Thesis Number 205427)

Crosson, J., \& Geers, A. (2001). Analysis of narrative ability in children with cochlear implants. Ear and Hearing, 22(5), 381-394.

Çıkrıkçı, S. S. (2008). İlköğretim öğrencilerinde özetleme becerisinin gelişimi [Primary school students summarizing skill development]. Dil Dergisi, 141(1), 19-35.

Day, J. D. (1980). Teaching summarization skills: A comparison of training methods. (Doctoral dissertation, University of Illinois at Urbana-Champaign). Retrieved from https://www.ideals.illinois.edu/handle/2142/66580

Deneme, S. (2009). İngilizce öğretmen adaylarının özetleme stratejilerini kullanım tercihleri [Preference for use in summarization strategies of English teacher candidates]. Journal of Language and Linguistic Studies, 5(2), 85-91.

De Villiers, P. (1991). English literacy development in deaf children: Directions for research and intervention. In J. Miller (Ed.), Research on child language disorders: A decade of progress (pp. 277-284). Austin TX: Pro-Ed.

Erdem, C. (2012). Türk dili ve edebiyatı öğretmen adaylarının özetleme stratejilerini kullanım tercihleri ve metin dil bilimsel bir özetleme çalışması [Summation strategies use preferences of Turkish language and literature teacher candidates and study of a text linguistics summation]. Dil ve Edebiyat Eğitimi Dergisi, $1(3), 36-52$.

Erdiken, B. (2010). İşitme engelli öğrencilere yazılı anlatım öğretiminde iki yaklaşım ve değerlendirme [Two approaches of teaching written expression for hearing impaired students andtheir assessment]. Milli Eğitim Dergisi, 39(186), 85-105.

Garner, R. (1982). Efficient text summarization costs and benefits. The Journal of Educational Research, 75(5), 275-279. 
Girgin, Ü. (2002). İşitme engelli çocuklarda yazma süreci [Writing process with hearing impairment]. 12. Ulusal Özel Eğitim Kongresi Kitapçığı: Yöntemler-Yaklaşımlar-Stratejiler. Ankara: Ankara Üniversitesi Eğitim Bilimleri Fakültesi Yayınları.

Gormley, K., \& Sarachan-Deily, B. (1987). Evaulating hearing impaired students' writing: A practical approach. Volta Rewiev, 89(3), 157-170.

Görgen, İ. (1997). Özetleme ve bilgi haritası oluşturma öğretiminin bilgilendirici bir metni öğrenme ve hattrlama düzeyine etkisi (Unpublished doktarate thesis) [The Effect of instruction of summarizing and knowledge -map formation to learning and recal leves of a expository text]. Hacettepe Üniversitesi Eğitim Bilimleri Enstitüsü, Ankara. Retrieved from http://tez.yok.gov.tr/UlusalTezMerkezi (Thesis Number 63890)

Graham, S., \& Harris, K. R. (2012). Writing better: Effective strategies for teaching students with learning difficulties. Baltimore: Brookers Publishing Company.

Güldenoğlu, B., Kargin, T., \& Miller, P. (2014). An investigation of the word processing skills of deaf and hearing readers. Türk Psikoloji Dergisi, 29(73), 18-43.

Güneş, F. (2007). Türkçe öğretimi ve zihinsel yapılandırma [Turkish teaching and mental structuring]. Ankara: Nobel Yayın Dağıtım.

Heefner, D. L., \& Shaw, P. C. (1996). Assessing the written narratives of deaf students using the six-trait analytical scale. Volta Review, 98(1), 47-68.

Hiebert, E. H., Englert, C. S., \& Brennan, S. (1983). Awareness of text structure in recognition and production of expository discourse. Journal of Reading Behavior, 15(4), 63-79.

Jitendra, A. K., \& Gajria, M. (2011). Reading comprehension instruction for students with learning disabilities. Focus on Exceptional Children, 43(8), 1-16.

Justice, L., Invernizzi, M., Geller, K., Sullivan, A., \& Welsch, J. (2005). Descriptive developmental performance of at-risk preschoolers on early literacy tasks. Reading Psychology, 26(1), 1-25.

Karasu, H. P. (2004). Kaynaştırmadaki işitme engelli öğrencilerin yazıll anlatım beceri düzeylerini değerlendirilmesi [Assessment of writing skills of hearing impaired students who attend mainstream classes] (Unpublished master's thesis, Anadolu University, Institute of Educational Sciences Eskişehir, Turkey). Retrieved http://tez.yok.gov.tr/UlusalTezMerkezi (Thesis Number 143978)

Karasu, H. P. (2014). İşitme yetersizliği olan öğrencilerin yazılı ürünleri gözden geçirme ve düzeltme evresine duydukları ihtiyacın belirlenmesi [Determination of hearing-impaired students' requirements for editing and revision of written texts]. Kuram ve Uygulamada Eğitim Bilimleri, 14(3), 1089-1109.

Karasu, H. P., \& Girgin, Ü. (2007). Kaynaştırmadaki işitme engelli öğrencilerin yazılı anlatım beceri düzeylerinin değerlendirilmesi [Assessment of writing skills of hearing impaired students who attend mainstream classes]. Anadolu Üniversitesi Sosyal Bilimler Dergisi, 7(1), 467-488.

Karasu, H. P., Girgin, Ü., \& Uzuner, Y. (2013). Okuma becerilerini değerlendirmede Formel Olmayan Okuma Envanteri. Ankara: Nobel Akademik Yayıncılık.

Kim, W., Linan-Thompson, S., \& Misquitta, R. (2012). Critical factors in reading comprehension instruction for students with learning disabilities: A research synthesis. Learning Disabilities Research \& Practice, 27(2), 66-78.

Klecan-Aker, J., \& Blondeau R. (1990). An examination of the written stories of hearing impaired school age children. Volta Rewiev, 92(6), 275-282. 
Korkmaz, Z. (2003). Türkiye Türkçesi grameri (Şekil bilgisi). Ankara: TDK Yayınları.

Marschark, M., \& Wauters, L. (2008). Language comprehension and learning by deaf students. In M. Marschark \& P. C. Hauser (Eds.), Deaf Cognition: Foundations and Outcomes (pp. 309-350). New York: Oxford University Press.

Marschark, M., Lang, H. G., \& Albertini, J. A. (2002). Educating deaf students: From research to practice. New York: Oxford University Press.

Marschark, M., Mouradian, V., \& Hallas, M. (1994). Discourse rules in the language productions of deaf and hearing children. Journal of Experimental Psychology, 57(1), 89-107.

Maxwell, M., \& Falick, T. (1992). Cohesion and quality in deaf and hearing children's written English. Sign Language Studies, 77(1), 345-371.

Özkan, B. (2004). Metindilbilimi metindilbilimsel bağdaşıklık ve Haldun Taner'in onikiye bir var adlı öyküsünde metindilbilimsel bağdaşıklık görünümleri [Text linguistics and text linguistics cohesion at the story 'Onikiye Bir Var' by Haldun Taner]. Çukurova Üniversitesi Sosyal Bilimler Enstitüsü Dergisi, 13(1), 167-184.

Özkan, H. B. (2010). Koklear implant kullanan çocukların okuduklarını anlatma becerilerinin değerlendirilmesi [Evaluation of reading comprehension skills in children with cochlear implants] (Unpublished master's thesis, Hacettepe University Institute of Health Sciences, Ankara, Turkey). Retrieved from http://tez.yok.gov.tr/Ulusal Tez Merkezi/ (Thesis Number 267354)

Peterson, L. (1983). Summarization strategies of deaf and hearing adolescents. Unpublished manuscript. University of Rochester, Center for Psychological Development, Rochester, NY.

Peterson, L. (1986a). Summarization strategies of deaf and hearing college students. Paper presented at annual meeting of the American educational research association, San Francisco, CA.

Peterson, L. (1986b). Summary writing strategies of deaf college students: A discussion of a recent investigation. Quarterly Letter of the Teachers of Language Arts (Themes), 2(2), 5-6.

Peterson, L., \& French, L. (1988). Summarization strategies of hearing impaired and normally hearing college students. Journal of Speech and Hearing Research, 31 (3),327-337.

Ramadan, S. M. S. (2003). Cohesion in written works of the twelfth grade students of literary and scientific streams at state secondary schools in jordan (Unpublished doktarate thesis). Gazi University Institute of Educational Sciences, Ankara.

Schirmer, B. R. (2000). Language and literacy development in children who are deaf. Boston, MA: Allyn \& Bacon Inc.

Schirmer, B. R. (2001). Psychological, social and educational dimensions of deafness. Boston: Allyn and Bacon.

Seçkin, P., Arslan, N., \& Ergenç, S. (2014). Bağdaşıklık ve tutarlılık bakımından lise ve üniversite öğrencilerinin yazılı anlatım becerileri [Writing skills of high school and university students in terms of coherence and consistency]. Uluslararası Türkçe Edebiyat Kültür Eğitim Dergisi, 3(1), 340-353.

Senemoğlu, N. (2005). Gelişim, öğrenme ve öğretim: Kuramdan uygulamaya (12. Bask1) [Development, learning and instruction: From theory to application]. Ankara: Gazi Kitabevi.

Singer, B., \& Bashir, A. (2004). Developmental variation in writing composition skills. In C. Stone, E. Silliman, B. Ehren \& K. Apel (Eds.), Handbook of language and literacy: Development and disorders (pp. 559582). New York: Guilford Press. 
Solomon, P. (2012). The effects of graphic organizers on improving the summarizing skills of fourth grade students (Master's thesis). Retrieved from http://search.proquest.com/

Strassman, B. K. (1997). Metacognition and reading in children who are deaf: A review of the research. Journal of Deaf Studies and Deaf Education, 2(3), 140-149.

Tarchi, C. (2015). Fostering reading comprehension of expository texts through the activation of readers' prior knowledge and inference-making skills. International Journal of Educational Research, 72, 80-88.

Tiryaki, E. N. (2014). Ortaokulda öğrenim gören işitme engelli öğrencilerin okuduğunu anlama becerilerinin çeşitli değişkenler açısından değerlendirilmesi [Multivariable evaulation of reading comprehension skills deaf students at secondary school]. Mustafa Kemal Üniversitesi Sosyal Bilimler Enstitüsü Dergisi, 11(26), 247-258

Tok, Ş., \& Beyazıt, N. (2007). İlköğretim 3. sınıf Türkçe dersinde özetleme ve not alma stratejilerinin okuduğunu anlama ve kalıcılık üzerindeki etkileri [Effects of summary and note taking strategies on reading comprehension and retention]. Eurasian Journal of Educational Research, 28 (2),113-122.

Tompkins, G. E. (2006). Literacy for the 21st century. A balanced approach (4th ed.). New Jersey: Pearson Merrill Prentice Hall.

Turğut, N. (2012). Işsitme engelli 10-14 yaş arası çocuklarda işitme düzeyi ile yazılı dil becerisi ilişkisinin incelenmesi [Examination of relationship between written language skills and level of hearing in 10-14 years old hearing impaired children] (Unpublished master's thesis, Firat University, Institute of Health Sciences, Elazı̆g, Turkey). Retrieved from http://tez.yok.gov.tr/Ulusal Tez Merkezi. (Thesis Number 334229).

Tüfekçioğlu, U. (1992). Kaynaştırmadaki işitme engelli çocuklar: Eskişehir ilindeki normal okullarda eğitim gören işitme engelli ögrencilerin durumu [Hearing-impaired children in mainstreamed: The situation of hearingimpaired students studying in normal schools in Eskişehir]. Eskişehir: Anadolu Üniversitesi Yayınları.

Varonis, E. M., \& Gass, S. M. (1985). Miscommunication in native/nonnative conversation. Language in Society, 14(3), 327-343.

Vaughn, S., Linan-Thompson, S., \& Hickman-Davis, P. (2003). Response to treatment as a means for identifying students with reading/learning disabilities. Exceptional Children, 69(4), 391-410.

Westby, C., Culatta, B., Lawrence, B., \& Hall-Kenyon, K. (2010). Summarizing expository texts. Topics in Language Disorders, 30(4), 275-287.

Yılmaz, Ö. (2012). 11. Sinıf öğrencilerine ait öyküleyici metinlerin bağdaşıklık ve tutarlılık açısından incelenmesi [The research of narrative texts of 2. grade students in the way of coherence and cohesion]. (Master's Thesis, Bülent Ecevit University, Institute of Social Sciences, Zonguldak, Turkey). Retrieved from http://tez.yok.gov.tr/UlusalTezMerkezi. (Thesis Number 322226)

Yoshinaga-Itano, C., \& Downey, D. M. (1996). The effect of hearing loss on the development of metacognitive strategies in written language. Volta Review, 98(1), 97-143.

Yoshinaga-Itano, C., \& Downey, D. M. (1992). When a story is not a story: A process analysis of the written language of hearing-impaired children. Volta Review, 94(2), 131-58.

Yoshinaga-Itano, C., Snyder, L. S., \& Mayberry, R. (1996a). Can lexical/semantic skills differentiate deaf or hard of hearing readers and non-readers? The Volta Review, 98(1), 39-61.

Yoshinaga-Itano, C., Snyder, L. S., \& Mayberry, R. (1996b). How deaf and normally hearing students convey meaning within and between written sentences. The Volta Review, 98(1), 9-38. 


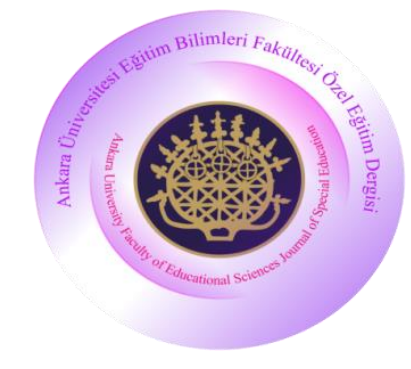

RESEARCH

\section{Ankara University Faculty of Educational Sciences Journal of Special Education}

Year: 2018, Volume: 19, No: 3, Page No: 531-551

DOI: 10.21565/ozelegitimdergisi.348310

\title{
Comparative Examination of Summarizing Skills of Students with and without Hearing Impairments
}

\author{
Halime Miray Sümer \\ Niğde Ömer Halisdemir University
}

\author{
Cebrail Turna \\ Ankara University
}

\begin{abstract}
In this study, it was aimed to examine the cohesion level and summarizing skills of narrative texts of students with and without hearing impairment who were studying in the eighth grade. The study group consisted of 15 deaf students and 15 hearing students studying at eighth grade level in Ankara. Findings showed that there was a significant difference between students with and without hearing impairments in sub-dimensions of summarization and summarization total scores. Students with typical hearing were found to be more successful than the deaf students in terms of meeting the summarizing criteria. Students with typical hearing were found to be higher than students with hearing impairments in the sub-dimensions of the cohesion items and mean average in the frequency in using the cohesion items. There was no significant difference between students with and without hearing impairments in the subscale of subsitution of cohesion level.
\end{abstract}

Keywords: Students with hearing impairments, summarizing skills, cohesion.

\section{Recommended Citation}

Sümer, H. M., \& Turna, C. (2018). Investigation in the way of summarizing skills of students with and without hearing impairments. Ankara University Faculty of Educational Sciences Journal of Special Education, 19(3), 531-551. doi: 10.21565/ozelegitimdergisi.348310

${ }^{*}$ Corresponding Author: Res. Assist, E-mail: miraysumer@gmail.com, http://orcid.org/0000-0002-1470-8195

${ }^{* *}$ Res. Assist., E-mail: cebrailturna@ gmail.com, https://orcid.org/0000-0002-3817-1951 
While competence in reading skills is a sign of successful academic performance, the limitations experienced in this skill are also important factors in academic failure. Reading is the process of extracting meaning from written symbols with the most general definition. When the definitions of reading in the literature are examined, it is seen that the reading takes place in two steps, processing and comprehension, and the main purpose is the reading comprehension. Reading without comprehension can only be called pronunciation. One of the methods of evaluating comprehension, which is evaluated formally and informally, is summarizing the texts that the students read (Braxton, 2009; Cavkaytar, 2010; Jitendra and Gajria, 2011; Solomon, 2012). Summarization means that the reader is shortening the flow of the text and shortening the text with his own sentences to contain important information (Aktaş and Bayram, 2017; Braxton, 2009; Çıkrıkç1, 2008; Deneme, 2009; Görgen, 1997). As it is understood from the definition, the summarizing is not memorizing a sentence in the text, but it is the way of expressing the main thought by separating the important points in the text from the less important ones. In summarizing, the individual also fulfills a number of cognitive tasks such as analyzing, classifying, drawing conclusions, and making inferences (Erdem, 2012). When reviewing the literature, it is seen that summarizing skill facilitates the recall of information about the text and improves the reading comprehension performance (Calhoon, 2005; Calp, 2010; Graham and Harris, 2012, Kim, Linan-Thompon and Misquitta, 2012, Westby, Culatta, Lawrence and Hall-Kenyon, 2010).

Summarization skill (Senemoğlu, 2005; Tok and Beyazit, 2007), which is related to both reading and writing skills, is not a spontaneous skill but a skill gained through teaching (Akyol, 2008; Anderson, Hidi and Babadoğan, 1991). In order to make a successful and effective summarization, students need to understand the text well, distinguish important places from unimportant ones, avoid disturbing the flow of events, avoid excessive word usage, and pay attention to punctuation marks and writing rules (Beyreli, Çetindağ and Celepoğlu, 2005; Güneş, 2007). In addition, factors such as the structure of the text, age of the reader, and reading experiences influence the summarization (Akyol, 2008; Tompkins, 2006).

According to Akyol (2008), narrative texts are more easily summarized than other text types. Explanatory and informative texts are more difficult to summarize because of more complex and greater number of words that readers do not know (Anderson et al., 1991). Bulut (2013) has studied students' summarizing performances with 561 students in the $5^{\text {th }}$ grade and concludes that students are more successful than informative texts in the type of narrative text. One of the criteria affecting summarization other than text type is the age of the reader (Bulut, 2013). Summarization was defined in terms of the following measures: deletion of trivial text information, inclusion of most important ideas, selection of topic sentences, creation of topic statements, and integration of information within and among several paragraphs. Summarizing performances are higher because readers have more reading experience as their age progresses.

The texts make sense as a whole depending on the relationship and interaction between the sentences (Özkan, 2004). Accordingly, seven items seem to be important to create a product. These include; coherence, cohesion, purposefulness, inter-text relationship, acceptability, informativeness, and situation (De Beaugrande and Dressler, 1981: akt., Coşkun, 2005). The sentences that make up the text have to be in a relationship with one another. For this reason, sentences are not independent from each other, but rather complement each other. Holding the text together, make the text meaningful, what distinguishes text from non-text expression are cohesion (Halliday and Hasan, 1976; akt., Coşkun, 2005). The most common definition of the cohesion is that the whole set of language-related features that allow something to be written as a text and the continuity of the text (Y1lmaz, 2012; Dillon, 1992: akt., Coşkun, 2005). We used cohesion scale developed by Coşkun (2005). Cohesion consists of four categories: (1) reference, (2) substitution, (3) ellipsis, and (4) conjunction.

Reference; a concept or entity expressed in the text is to be expressed as another word or appendix, rather than being repeated in close sentences and in the same sentence. In Turkish, the reference items are made by personal pronouns, reflexive pronouns, demonstrative pronouns, relative pronouns, demonstrative adjectives, and comparisons adjectives (Coşkun, 2005). Ellipsis is a situation in which some words or structures are not used without making the narrative difficult, without confusing the meaning, and without loss of meaning (Coşkun, 2005; 
Yılmaz, 2012; Seçkin, Arslan and Ergenç, 2014). Thus, unnecessary repetitions are avoided. Ellipsis can be accomplished by extracting the possessive construction and some phrases. Another item that creates cohesion is substitution. In general, it means that one item is taken by another item (Coşkun, 2005; Yllmaz, 2012). Substituion is done in three ways: based on name, based on the sentence, and based on verb. Sentences and paragraphs that constitute a text must be related to each other. In order to be able to do this, there is a need for conjuction, which is another kind of cohesion. In this study, conjuctions were examined in the form of attaching, discriminating, contrasting, time-ordering, conditional, annotation, sampling, and cause and effect relation.

The study by Tiryaki (2014) examined the problems in written texts of students with hearing impairment. A total of 40 hearing-impaired students attending the $5^{\text {th }}, 6^{\text {th }}, 7^{\text {th }}$, and 8 th classes attended the study. As a result, it was found that students with hearing impairments had problems such as not paying attention to writing rules, not using attachments, making meaningless and complicated sentences about the subject, using punctuation marks incorrectly, and not creating paragraphs. Karasu and Girgin (2007) aimed to determine the level of written expression skill of the students with hearing impairments in the study. A total of 25 integration students with hearing impairments attending classes 4, 5, 6, 7, and 8 participated in the study. According to the findings of the research, students with hearing impairments were found to have problems in the fields of making headings, putting out the main idea, creating paragraphs, and complying with writing rules. In this study, it is considered that the text summarization and coherence levels of the students with hearing impairments are examined mutually with their peers and it is thought that to clarify the areas where they are inadequate in written expression is a guide for training and intervention studies to be done. The purpose of this study was to compare the cohesion level and summary writing skills of college students with ant without hearing impairments, in the $8^{\text {th }}$ grade. In response to this aim, the answers to the following questions were sought.

1. Do summarization scores in students' summaries differ significantly according to hearing status?

2. Do the students' cohesion scores show a significant difference according to hearing status?

\section{Method}

In this study, the summaries of students with and without hearing impairments in the $8^{\text {th }}$ grade are examined as a study in the cause-and-effect comparative model of descriptive research methods aimed at examining the level of cohesiveness and summarizing skills. 15 students with hearing impairments and 15 students without hearing impairments, totally $308^{\text {th }}$ graders participated in the study. To assess their summarizing skills, they were given a narrative text and then they were asked firstly to read it and after that summarize what they read. Six of the students with hearing impairments who participated in the study had moderate hearing loss and nine of them had severe hearing loss. According to the information received from the parents, 10 students used right ear and left ear, and 5 students used one ear hearing aid. Looking at the educational background of the students, all participants were educated in a school for students with hearing impairments from the age of the beginning of formal education.

Inclusion criteria of students with hearing impairments are as follows; a) having independent reading and writing skills indicated by their teachers, b) absence of any additional insufficiency identified other than hearing impairment, c) the criteria for legibility of the handwriting were sought. This research towards these criteria were included in the total of 15 middle school students with a hearing impairment totaling 8 girls and 7 boys.

Inclusion criteria of the students without hearing impairments; a) having independent reading and writing skills indicated by their teachers, b) absence of any additional disabilities identified, c) the criteria for legibility of the handwriting were sought. Within these criteria, a total of 15 students from the middle school totaling 8 girls and 7 boys participated in the research.

For the students to read, the "Sel (the Flood)" story named "Non-Formal Reading Inventory" prepared by Karasu, Girgin and Uzuner (2013, pp. 1-331) was used. "Summary Evaluation Form for Narrative Texts" was used to assess their summarizing skills and "Cohesion Measurement Tool" was used to determine of cohesion levels in 
summary texts. Each summary was scored for (a) format, (b) language and expression, (c) content, and (d) text format. Then summaries were scored for cohesion level: (a) conjuctions, (b) reference, (c) ellipsis, and (d) substitution. Two statistical methods were used for the purpose of the research. Firstly, the abstracts of the students were analyzed by descriptive analysis. Secondly, the Mann-Whitney U Test for Independent Samples was used to determine the differences between the groups.

\section{Results}

Findings showed that there was a significant difference between students with and without hearing impairments in sub-dimensions of summarization and summarization total scores. When comparing summarizing skills of the groups, it was seen that students with hearing impairments had more difficulties than students without hearing impairments in format criteria, language and expression criteria, content criteria, text format criteria, and summarization total scores. Students without hearing impairments were found to be more successful than the students with hearing impairments in terms of meeting the summarizing criteria.

A comparison of the total number of cohesion level in students with and without hearing impairments summaries showed that there were significant differences between groups in the mean average in the frequency in using the cohesion items. Compared to students with hearing impairments, students without hearing impairments significantly used more often: (a) conjuctions, (b) reference, and (c) ellipsis. There was no significant difference between the students with and without hearing impairments in the substitution subscale. It was seen that both students with and without hearing impairments did not use substitution items in their summaries.

\section{Discussion and Conclusion}

In this study, it was found that there was significant difference between the students with and without hearing impairments in the summarization skills. These results indicate that students with hearing impairments used summarizing skills $(\bar{X}=7.2)$ but their level of use is lower than their peers without hearing impairments $(\bar{X}=27.3)$. According to the content dimension of the summarizing, students with hearing impairments (1.73) performed poorly compared to students without hearing impairments (6.46). When we look at the format dimension, which is another sub-dimension, the students with hearing impairments (1.13) performed lower than the students without hearing impairments (4.26). Looking at the summaries of students with hearing impairments, it appears that students wrote a summary related to the story but did not write a title, did not specify the main idea, and did not use the page regularly. It is stated that students with hearing impairments find it difficult to use these skills and therefore their written narration is lagging behind their peers without hearing impairments (Antia, Reed and Kreimeyer, 2005; Girgin, 2002; Heefner and Shaw, 1996; Karasu, 2004; Peterson, 1986a, 1986b; YoshinagaItano and Downey, 1992). When the third sub-dimension was examined in terms of language and expression dimension, students with hearing impairments (1.40) performed poorly compared to students without hearing impairments (7.40). When students with hearing impairments were compared to students without hearing impairments, it was seen that there was no tense rules compliance in the summaries however most of the past time expressions were used. When looking at school-based instruction, it is often difficult for learners to reason with certain patterns and rules, and they are also having difficulty in using grammar skills.

According to the summaries of the students with hearing impairments, it is seen that the students with hearing impairments $(\bar{X}=2.93)$ have story structure even though they are not as good as the students without hearing impairments $(\bar{X}=9)$ as to text format (scenes, characters, and problem). When the summary of the students with hearing impairments were examined, they wrote about the place, character, problem knowledge of the given story but the information in the summary was not enough for the summary text format. These results show us how the students with hearing impairments should form the information that makes up the structure of the story, how to find it, and how to organize it, and write it down as a summary.

One explanation for these differences could be that the students with hearing impairments may have had difficulty distinguishing the important and insignificant information from the text summarizing the text which they 
read (Brown and Day, 1983; Day, 1980; Garner, 1982; Peterson, 1986a, 1986b; Peterson and French, 1988). Secondly, students with hearing impairments may have performed poorly when summarizing due to lack of metacognitive information compared to students without hearing impairments (Akamatsu, 1988; Alvermann, 1982; Benedict, Rivera and Antia, 2014; Hiebert, Englert and Brennan, 1983, Marschark and Wauters, 2008; Peterson and French, 1988, Strassman, 1997). Another interpretation of these results may be that students with hearing impairments might have a lower level of understanding of text than students without hearing impairments because summarization skills are related to text processing (Peterson and French, 1988). Because students with hearing impairments have difficulty establishing relationships between the paragraphs in the story and the whole, the summaries may be presented in a haphazard manner.

In this study, it was found that the students without hearing impairments used cohesion level much more than the students with hearing impairments did. When summarized by the students, it is seen that students without hearing impairments have more frequent conjuction and complex sentences than students with hearing impairments. Both students with and without hearing impairments did not to use substitution items. These findings are consistent with both national and international literature (Bae, 2001; Coşkun, 2005; Ramadan, 2003).

When the narratives written by the students with hearing impairments in the literature are examined, it is seen that the frequency of use of conjuction items is low (Burman, Evans, Nunes and Bell, 2008; Erdiken, 2010; Karasu and Girgin, 2007; Klecan-Aker and Blondeau, 1990; Yoshinaga-Itano and Downey, 1996). One explanation for these differences could be that of the students with hearing impairments were very careless in forming the in-text links and accordingly, they were not successful enough to benefit from cohesiveness tools. Secondly, because the texts written by the students are short, the frequency of use of cohesion tools may be low. Another interpretation of these results may be that the use of coherence tools is closely related to language development (Maxwell and Falick, 1992). The variables affecting the use of cohesion are both age progression and the nature of the education given to the students. According to the accepted view, as language development progresses, the use of cohesiveness tools is increasing (Coşkun, 2005: 226). When students with hearing impairments are deemed not to have the same language experience as students without hearing impairments, the $8^{\text {th }}$ grade students with hearing impairments who participated in this study might not be able to achieve sufficient level in terms of language development. Varonis and Gass (1985) state that as individuals do on a different language of reading, learners with hearing impairments have had a conclusion of the texts by guessing "what they meant to say."

The findings of this study show us that learners with hearing impairments need to use some important information in terms of reading and writing skills and encounter some more tasks that need to be defined. For example, teachers can perform activities such as re-organizing text semantically, extracting similar ideas in paragraphs or among paragraphs within a text. Students with hearing impairments should take a more active and conscious role in the reading task to be good at summarizing skills. The sub-dimensions of summarization skills should be taught to students or these skills should be developed. This should include not only the students' awareness of the importance of the information in the text but also how they can incorporate this information into the writing. In order to reach the goals students need to earn, the activities should be prepared according to the language and knowledge level of the students, diversification of materials used according to individual characteristics of students, and finally the training program should be organized for the needs of the students by systematically evaluating the students. In addition, it has been proven through extensive studies that activities aimed at the development of individual writing skills with students with hearing impairments have contributed to the development of their writing skills (Gormley and Sarachan-Deily, 1987; Karasu, 2014; Schirmer, 2000). Finally, this study was carried out with the narrative text, which is the type of text most frequently encountered since the beginning of the education period of the students. Nevertheless, the fact that the summaries of the students are very poor in terms of summarization skills and coherence suggests that more training and research are needed in this regard. A writing program related to their life experiences that will attract attention of students with hearing impairments students can help improve both the ability to use summarization skills and cohesion tool. 